\title{
Telomere length: biological marker of cellular vitality, aging, and health-disease process
}

\author{
Marcus Zulian Teixeira ${ }^{1 *}$ (1)
}

\begin{abstract}
SUMMARY
The aging process occurs due to the decline of vital physiological functions and adaptability of the body, being influenced by genetics and lifestyle. With advances in genetics, biological aging can be calculated by telomere length. Telomeres are regions at the ends of chromosomes that play a role in the maintenance and integrity of DNA. With biological aging, telomere shortening occurs, causing cellular senescence. Several studies show that shorter telomeres are associated with acute and chronic diseases, stress, addictions, and intoxications. Even in the current COVID-19 pandemic, telomere shortening is proposed as a marker of severity in individuals infected by the severe acute respiratory syndrome coronavirus 2 (SARS-CoV-2). On the other hand, healthy lifestyle habits increase telomere length and balance of various cellular functions, preventing diseases.

KEYWORDS: Telomere. Telomere shortening. Telomere homeostasis. Telomerase. Biomarkers. Aging. Cellular senescence. Chronic disease.
\end{abstract}

\section{INTRODUCTION}

The irreversible aging process is marked by a decline in vital physiological functions and the adaptability of the body, being strongly influenced by genetics, environmental factors, and lifestyle. Currently, the aging process is divided into two main components, namely, chronological age and biological age, which may differ for the same individual. Biological aging can be calculated by telomere length (TL $)^{1,2}$ and DNA methylation levels (epigenetics) ${ }^{3,4}$.

Telomeres are noncoding regions of the genome, located at the ends of chromosomes (functioning as protective covers of chromosomes), which consist of long series of short and repeated sequences formed by nitrogen bases 5'-TTAGGG-3' and associated proteins, which play an important role in the maintenance and integrity of DNA. Telomere shortening may compromise the replicative potential of cells, contributing to the natural process of cellular senescence. To counteract this process, the telomerase enzyme promotes the maintenance of telomere length by synthesizing the repetitive sequences of lost telomeric DNA.
In 2009, Elizabeth H. Blackburn, Carol W. Greider, and Jack W. Szostak received the Nobel Prize in Physiology or Medicine for discovering the protective role of telomere and telomerase enzyme in chromosomes ${ }^{5-7}$. These extremely significant findings paved the way for researchers to further explore the role of telomere homeostasis in cell aging and chronic diseases in general.

\section{Mechanism of action of Telomeres}

During cell division or duplication, cells are unable to replicate approximately 50 pairs of nitrogen bases from the ends of chromosomes, as conventional DNA polymerase cannot reproduce the $3^{\prime}$ end of a linear molecule (end replication problem). This leads to progressive chromosome shortening along the divisions of a cell lineage, resulting in loss of replicative capacity and induction of cellular senescence. This mechanism of action is the main cause of cell aging and age-related chronic diseases ${ }^{8-10}$.

To avoid this progressive telomere shortening that occurs at each cell division and the loss of respective genetic information,

\footnotetext{
'Instituto de Psiquiatria, Hospital das Clinicas, Faculdade de Medicina - Universidade de São Paulo (SP), Brazil.

*Corresponding author: marcus@homeozulian.med.br

Conflicts of interest: the authors declare there are no conflicts of interest. Funding: none.

Received on August 18, 2020. Accepted on August 19, 2020.
} 
periodically, the lost DNA segments are recovered by the action of a ribonucleoprotein enzyme complex called telomerase. This complex has a small RNA component that is a template for the synthesis of the repetitive sequences, which make up the telomere. In the recovery of lost telomeric DNA, nucleotide bases are added individually and in the correct sequence, and telomerase progresses discontinuously, i.e., the RNA mold is positioned on the initiator DNA, several nucleotides are added to it, and finally the enzyme translocates to restart the process ${ }^{10-12}$.

In neonatal period, telomerase activity is reduced or null, as evident from the absence in most somatic tissues of the body. Telomerase is active in early stages of human development (pluripotent embryonic cells), and throughout life, in blood stem cells, germ cells and cells of adult tissues undergoing continuous renewal, such as endometrial tissue ${ }^{13}$. Due to gradual loss of telomerase activity, in each cell division, the telomere terminals of these cells are shortened, reaching a minimum length that precludes cell division ${ }^{14}$.

On the other hand, $90 \%$ of cancerous somatic cells, which reach "immortality," have high expressiveness of telomerase (increasing the telomere length). In these tumor cells, the reactivation of the telomerase silencer gene has been one of the mechanisms used to circumvent the natural system of cellular senescence and apoptosis, allowing cancer cells to promote continuous telomere elongation and replicate in an uncontrolled and uninterrupted manner ${ }^{15,16}$.

\section{Role of Telomeres in health disorders}

Several studies show that shorter telomeres are associated with a number of chronic diseases: congenital dyskeratosis, aplastic anemia, idiopathic pulmonary fibrosis, and liver cirrhosis ${ }^{17}$; cardiovascular diseases in general ${ }^{18,19}$, such as atherosclerosis ${ }^{20}$, arterial hypertension ${ }^{21}$, and $\operatorname{stroke}^{22}$; diabetes mellitus type $2^{23-25}$; autoimmune diseases, such as systemic lupus erythematosus $^{26}$ and rheumatoid arthritis ${ }^{27}$; psychiatric diseases ${ }^{28}$; and dementia ${ }^{29,30}$, among other age-related diseases ${ }^{31}$.

In cancer, telomere sizes play a dual role as follows: telomere shortening can lead to the induction of chromosomal instability and the onset of tumor formation (precancerous lesion); on the other hand, initiated tumors need to reactivate telomerase to stabilize chromosomes and gain "immortal" growth capacity ${ }^{32,33}$.

The same telomere shortening is observed in other health disorders, addictions, and intoxications, namely: obesity ${ }^{34}$; inflammatory and oxidative processes ${ }^{35}$; smoking $^{36}$, alcoholism $^{37}$ and drug dependence ${ }^{38}$; and exposure to pollutants and mineral particles ${ }^{39-41}$, among the others.

Even in acute diseases, such as the current coronavirus disease 2019 (COVID-19), telomere shortening is proposed as a marker of disease severity ${ }^{42,43}$ identifying patients at risk of higher morbidity and mortality from severe acute respiratory syndrome coronavirus 2 (SARS-CoV-2) infection. Studies suggest that T-cell lymphopoiesis may be discontinued in the infected individuals with short telomeres ${ }^{44}$.

In cancer-surviving children, a study shows the decrease in telomere size associated with chronic health disorders as a result of the treatment received (radiotherapy and chemotherapy $)^{45}$. Similarly, other treatments have demonstrated the same shortening effect on telomere (e.g., immunosuppressive drugs $^{46}$, proton pump inhibitors ${ }^{47}$, and insulin $\left.{ }^{48}\right)$.

On the other hand, some therapies are being assessed to counteract telomere shortening and act on telomere diseases: sex hormones (aplastic anemia and idiopathic pulmonary fibrosis) $)^{17,49}$, antidiabetic agents without acarbose (type 2 diabetes) ${ }^{50}$ and lithium (bipolar disorder) ${ }^{51}$, among the others. Similarly, natural compounds and their extracts have demonstrated to increase telomerase activation (Astragalus membranaceus or TA-65, Centella asiatica, Euterpe oleracea, oleanolic acid, maslinic acid, and multi-nutrient formulas) ${ }^{17,52,53}$, which may be indicated in the treatment of diseases related to telomere shortening.

Given that in most cancer cells telomerase activity is higher, different anti-cancer approaches have been designed in the search for telomerase inhibitors: small-molecule inhibitors, antisense oligonucleotides (imetelstat), G-quadruplex stabilizers, immunotherapy, gene therapy using telomerase promoter-driven expression of a suicide gene, and chemicals that block telomerase biogenesis ${ }^{17,54,55}$. Among the natural compounds, anthraquinone ${ }^{56}$ and wogonin (extract from Scutellaria baicalensis $)^{57}$ appear as promising anti-tumor agents.

Analogous to physical disorders, traumatic social exposures or lifelong psychoemotional disorders, such as chronic stress and childhood traumas (abuse, violence, racism, bulling, low socioeconomic status, maternal depression, family disorder, and institutionalization, etc.), also cause a decrease in telomere length ${ }^{58-65}$.

Finally, in addition to natural and chronological aging, telomere shortening can be influenced by physical activity, body mass index, chronic inflammation, oxidative stress, hormone therapy, drugs, dietary antioxidants, and vitamins, among others. Studies show that individuals who follow a healthy lifestyle have longer telomeres ${ }^{66}$.

\section{CONCLUSION}

Functioning as an important biomarker of cellular vitality or activity, longevity or aging, and the health-disease process, measuring the telomere length of leukocytes DNA extracted from peripheral blood ${ }^{67}$ provides clinical and dynamic parameters of health and well-being and can be used as a diagnostic and prognostic method of the illness process ${ }^{31,68-70}$, as well as 
measuring the efficacy and effectiveness of various therapies employed, conventional ${ }^{71}$ or nonconventional (e.g., homeopathy $^{72}$, acupuncture ${ }^{73}$, and meditation ${ }^{74}$ ).

According to vitalist medical rationalities ${ }^{75}$, such as homeopathy and acupuncture, cellular activity, physiological homeostasis, and the health-disease process would be related to vital force or chi (tsri), respectively; cellular senescence, physiological imbalance, and the disease manifestation would occur due to the disturbance of the body vitality. In order to approximate different rationalities, recent studies correlate the characteristics and properties of the homeopathic vital principle with those of the genome (exome plus epigenome), suggesting that the genome would be the biological representation or substrate of the organic vital force, according to biomedical episteme ${ }^{76,77}$. In this context, the telomere length could be used as an important biomarker of the effectiveness of homeopathic treatment in maintaining vitality, physiological balance, and health.

Current knowledge about telomeres and telomerase reiterates the importance that should be devoted to healthy lifestyle and health-promoting measures, such as regular physical activity, balanced diet, body weight control, spiritual and contemplative activities, and integrative and complementary practices in health, that increase telomere length and balance of various cellular functions, preventing diseases, and other somatic and psychic disorders.

\section{REFERENCES}

1. Müezzinler A, Zaineddin AK, Brenner H. A systematic review of leukocyte telomere length and age in adults. Ageing Res Rev. 2013;12(2):509-19. https://doi.org/10.1016/j.arr.2013.01.003

2. Zhang WG, Zhu SY, Bai XJ, Zhao DL, Jian SM, Li J, et al. Select aging biomarkers based on telomere length and chronological age to build a biological age equation. Age (Dordr). 2014;36:9639. https://doi.org/10.1007\%2Fs11357014-9639-y

3. Field $A E$, Robertson NA, Wang T, Havas A, Ideker T, Adams PD. DNA Methylation Clocks in Aging: Categories, Causes, and Consequences. Mol Cell. 2018;71(6):882-95. https://doi. org/10.1016\%2Fj.molcel.2018.08.008

4. Gutman D, Rivkin E, Fadida A, Sharvit L, Hermush V, Rubin E, et al. Exceptionally Long-Lived Individuals (ELLI) demonstrate slower aging rate calculated by DNA methylation clocks as possible modulators for healthy longevity. Int J Mol Sci. 2020;21(2):615. https://doi.org/10.3390/ijms21020615

5. Blackburn E, Greider C, Yonath A, Ostrom E. 2009 Nobels: break or breakthrough for women? Interview by Jeffrey Mervis and Kate Travis. Science. 2009;326(5953):656-8. https://doi. org/10.1126/science.326_656

6. Blackburn EH. Telomeres and telomerase: the means to the end (Nobel lecture). Angew Chem Int Ed Engl. 2010;49(41):740521. https://doi.org/10.1002/anie.201002387

7. Blackburn E, Tucker E. Q\&A: End-game winner. Nature. 2015;526(7574):S56-7. https://doi.org/10.1038/526S56a

8. Pfeiffer $\mathrm{V}$, Lingner J. Replication of telomeres and the regulation of telomerase. Cold Spring Harb Perspect Biol. 2013;5:a010405. https://doi.org/10.1101\%2Fcshperspect.a010405

9. Maestroni L, Matmati S, Coulon S. Solving the telomere replication problem. Genes (Basel). 2017;8(2). https://doi. org/10.3390\%2Fgenes8020055

10. Saretzki G. Telomeres, telomerase and ageing. Subcell Biochem. 2018;90:221-308. https://doi.org/10.1007/978-981-13-28350_9

11. Cong YS, Wright WE, Shay JW. Human telomerase and its regulation. Microbiol Mol Biol Rev. 2002;66:407-25. https:// doi.org/10.1128\%2FMMBR.66.3.407-425.2002
12. Nicholls C, Li H, Wang JQ, Liu JP. Molecular regulation of telomerase activity in aging. Protein Cell. 2011;2(9):726-38. https://doi.org/10.1007\%2Fs13238-011-1093-3

13. Dracxler RC, Oh C, Kalmbach K, Wang F, Liu L, Kallas EG, et al. Peripheral blood telomere content is greater in patients with endometriosis than in controls. Reprod Sci. 2014;21(12):146571. https://doi.org/10.1177/1933719114527353

14. Giardini MA, Segatto M, da Silva MS, Nunes VS, Cano MI. Telomere and telomerase biology. Prog Mol Biol Transl Sci. 2014;125:1-40. https://doi.org/10.1016/B978-0-12-397898$1.00001-3$

15. Maciejowski J, Lange T. Telomeres in cancer: tumour suppression and genome instability. Nat Rev Mol Cell Biol. 2017;18(3):175 https://doi.org/10.1038\%2Fnrm.2016.171

16. Shay JW, Wright WE. Telomeres and telomerase: three decades of progress. Nat Rev Genet. 2019;20(5):299-309. https://doi. org/10.1038/s41576-019-0099-1

17. Martínez P, Blasco MA. Telomere-driven diseases and telomeretargeting therapies. J Cell Biol. 2017;216(4):875-87. https:// doi.org/10.1083\%2Fjcb.201610111

18. Haycock PC, Heydon EE, Kaptoge S, Butterworth AS, Thompson A, Willeit P. Leucocyte telomere length and risk of cardiovascular disease: Systematic review and meta-analysis. BMJ. 2014;349:g4227. https://doi.org/10.1136\%2Fbmj.g4227

19. Zhan $Y$, Hägg S. Telomere length and cardiovascular disease risk. Curr Opin Cardiol. 2019;34(3):270-4. https://doi.org/10.1097/ hco. 0000000000000613

20. Aviv A, Kark JD, Susser E. Telomeres, atherosclerosis, and human longevity: a causal hypothesis. Epidemiology. 2015;26:295-9. https://doi.org/10.1097\%2FEDE.0000000000000280

21. Tellechea ML, Pirola CJ. The impact of hypertension on leukocyte telomere length: a systematic review and meta-analysis of human studies. J Hum Hypertens. 2017;31(2):99-105. https:// doi.org/10.1038/jhh.2016.45

22. Jin $X$, Pan B, Dang $X, W u ~ H, X u$ D. Relationship between short telomere length and stroke: A meta-analysis. Medicine (Baltimore). 2018;97(39):e12489. https://doi.org/10.1097\% 2FMD.0000000000012489 
23. Willeit P, Raschenberger J, Heydon EE, Tsimikas S, Haun $M$, Mayr A, et al. Leucocyte telomere length and risk of type 2 diabetes mellitus: new prospective cohort study and literature-based meta-analysis. PLoS One. 2014;9:e112483. https://doi.org/10.1371\%2Fjournal.pone.0112483

24. Wang J, Dong X, Cao L, Sun Y, Qiu Y, Zhang Y, et al. Association between telomere length and diabetes mellitus: a metaanalysis. J Int Med Res. 2016;44(6):1156-73. https://doi. org/10.1177\%2F0300060516667132

25. Tamura Y, Takubo K, Aida J, Araki A, Ito H. Telomere attrition and diabetes mellitus. Geriatr Gerontol Int. 2016;16(Suppl 1):66-74. https://doi.org/10.1111/ggi.12738

26. Lee YH, Jung JH, Seo YH, Kim JH, Choi SJ, Ji JD, et al. Association between shortened telomere length and systemic lupus erythematosus: a meta-analysis. Lupus. 2017;26(3):282-8. https://doi.org/10.1177\%2F0961203316662721

27. Lee $\mathrm{YH}$, Bae SC. Association between shortened telomere length and rheumatoid arthritis: A meta-analysis. Z Rheumatol. 2018;77(2):160-7. https://doi.org/10.1007/s00393-016-0209-9

28. Muneer A, Minhas FA. Telomere biology in mood disorders: an updated, comprehensive review of the literature. Clin Psychopharmacol Neurosci. 2019;17(3):343-63. https://doi. org/10.9758\%2Fcpn.2019.17.3.343

29. Kuźma E, Hannon E, Zhou A, Lourida I, Bethel A, Levine DA, et al. Which Risk factors causally influence dementia? A systematic review of mendelian randomization studies. J Alzheimers Dis. 2018;64(1):181-93. https://doi.org/10.3233\%2FJAD-180013

30. Fani L, Hilal S, Sedaghat S, Broer L, Licher S, Arp PP, et al. Telomere length and the risk of Alzheimer's disease: The Rotterdam study. J Alzheimers Dis. 2020;73(2):707-14. https:// doi.org/10.3233/jad-190759

31. Herrmann M, Pusceddu I, März W, Herrmann W. Telomere biology and age-related diseases. Clin Chem Lab Med. 2018;56(8):1210-22. https://doi.org/10.1515/cclm-2017-0870

32. Raynaud CM, Sabatier L, Philipot O, Olaussen KA, Soria JC. Telomere length, telomeric proteins and genomic instability during the multistep carcinogenic process. Crit Rev Oncol Hematol. 2008;66(2):99-117. https://doi.org/10.1016/j. critrevonc.2007.11.006

33. Meena J, Rudolph KL, Günes C. Telomere dysfunction, chromosomal instability and cancer. Recent Results Cancer Res. 2015;200:6179. https://doi.org/10.1007/978-3-319-20291-4_3

34. Müezzinler A, Mons U, Dieffenbach AK, et al. Body mass index and leukocyte telomere length dynamics among older adults: results from the ESTHER cohort. Exp Gerontol. 2016;74:1-8. https://doi.org/10.1016/j.exger.2015.11.019

35. Zhang J, Rane G, Dai X, Shanmugam MK, Arfuso F, Samy $\mathrm{RP}$, et al. Ageing and the telomere connection: an intimate relationship with inflammation. Ageing Res Rev. 2016;25:5569. https://doi.org/10.1016/j.arr.2015.11.006

36. Müezzinler A, MonsU, Dieffenbach AK, Butterbach K, Saum KU, Schick $M$, et al. Smoking habits and leukocyte telomere length dynamics among older adults: results from the ESTHER cohort. Exp Gerontol. 2015;70:18-25. https://doi.org/10.1016/j.exger.2015.07.002

37. Martins de Carvalho L, Wiers CE, Manza P, Sun H, Schwandt $M$, Wang GJ, et al. Effect of alcohol use disorder on cellular aging. Psychopharmacology (Berl). 2019;236(11):3245-55. https://doi.org/10.1007/s00213-019-05281-5

38. Tannous J, Mwangi B, Hasan KM, Narayana PA, Steinberg JL, Walss-Bass C, et al. Measures of possible allostatic load in comorbid cocaine and alcohol use disorder: brain white matter integrity, telomere length, and anti-saccade performance. PLoS One. 2019;14(1):e0199729. https://doi. org/10.1371\%2Fjournal.pone.0199729

39. Hoxha M, Dioni L, Bonzini M, Pesatori AC, Fustinoni S, Cavallo $D$, et al. Association between leukocyte telomere shortening and exposure to traffic pollution: a cross-sectional study on traffic officers and indoor office workers. Environ Health. 2009;8:41. https://doi.org/10.1186\%2F1476-069X-8-41

40. McCracken J, Baccarelli A, Hoxha M, Dioni L, Melly S, Coull $B$, et al. Annual ambient black carbon associated with shorter telomeres in elderly men: veterans affairs normative aging study. Environ Health Perspect. 2010;118(11):1564-70. https:// doi.org/10.1289\%2Fehp.0901831

41. Sanei B, Zavar Reza J, Momtaz M, Azimi M, Zare Sakhvidi MJ. Occupational exposure to particulate matters and telomere length. Environ Sci Pollut Res Int. 2018;25(36):36298-305. https://doi.org/10.1007/s11356-018-3486-9

42. Salimi S, Hamlyn JM. COVID-19 and crosstalk with the hallmarks of aging. J Gerontol A Biol Sci Med Sci. 2020;glaa149. https:// doi.org/10.1093/gerona/glaa149

43. Maremanda KP, Sundar IK, Li D, Rahman I. Age-dependent assessment of genes involved in cellular senescence, telomere and mitochondrial pathways in human lung tissue of smokers, COPD and IPF: associations with SARS-CoV-2 COVID-19 ACE2-TMPRSS2-Furin-DPP4 axis. Res Sq. 2020;rs.3.rs-35347. https://doi.org/10.21203/rs.3.rs-35347/v1

44. Aviv A. Telomeres and COVID-19. FASEB J. 2020;34(6):724752. https://doi.org/10.1096/fj.202001025

45. Song N, Li Z, Qin N, Howell CR, Wilson CL, Easton J, et al. Shortened leukocyte telomere length associates with an increased prevalence of chronic health conditions among survivors of childhood cancer: a report from the St. Jude lifetime cohort. Clin Cancer Res. 2020;26(10):2362-71. https:// doi.org/10.1158/1078-0432.ccr-19-2503

46. Welzl K, Kern G, Mayer G, Weinberger B, Säemann MD, Sturm $G$, et al. Effect of different immunosuppressive drugs on immune cells from young and old healthy persons. Gerontology. 2014;60(3):229-38. https://doi.org/10.1159/000356020

47. Yepuri G, Sukhovershin R, Nazari-Shafti TZ, Petrascheck M, Ghebre YT, Cooke JP. Proton pump inhibitors accelerate endothelial senescence. Circ Res. 2016;118(12):e36-42. https://doi.org/10.1161\%2FCIRCRESAHA.116.308807

48. Zeng JB, Liu HB, Ping F, Li W, Li YX. Insulin treatment affects leukocyte telomere length in patients with type 2 diabetes: 6-year longitudinal study. J Diabetes Complications. 2019;33(5):363-7. https://doi.org/10.1016/j.jdiacomp.2019.02.003

49. Townsley DM, Dumitriu B, Liu D, Biancotto A, Weinstein B, Chen $C$, et al. Danazol treatment for telomere diseases. N Engl J Med. 2016;374(20):1922-31. https://doi.org/10.1056/ nejmoa1515319

50. Liu J, Ge Y, Wu S, Ma D, Xu W, Zhang Y, et al. Association between antidiabetic agents use and leukocyte telomere shortening rates in patients with type 2 diabetes. Aging (Albany NY). 2019;11(2):741-55. https://doi.org/10.18632/ aging. 101781

51. Lundberg M, Biernacka JM, Lavebratt C, Druliner B, Ryu E, Geske J, et al. Expression of telomerase reverse transcriptase positively correlates with duration of lithium treatment in bipolar disorder. Psychiatry Res. 2020;286:112865. https:// doi.org/10.1016/j.psychres.2020.112865 
52. Tsoukalas D, Fragkiadaki P, Docea AO, Alegakis AK, Sarandi E, Thanasoula M, et al. Discovery of potent telomerase activators: unfolding new therapeutic and anti-aging perspectives. Mol Med Rep. 2019;20(4):3701-8. https://doi.org/10.3892/ mmr.2019.10614

53. Souza-Monteiro JR, Arrifano GPF, Queiroz AIDG, Mello BSF, Custódio CS, Macêdo DS, et al. Antidepressant and antiaging effects of Açaí (Euterpe oleracea Mart.) in Mice. Oxid Med Cell Longev. 2019;2019:3614960. https://doi. org/10.1155/2019/3614960

54. Trybek T, Kowalik A, Góźdź S, Kowalska A. Telomeres and telomerase in oncogenesis. Oncol Lett. 2020;20(2):1015-27. https://doi.org/10.3892/ol.2020.11659

55. Liu C, Zhou H, Sheng XB, Liu XH, Chen FH. Design, synthesis and SARs of novel telomerase inhibitors based on BIBR1532. Bioorg Chem. 2020;102:104077. https://doi.org/10.1016/j. bioorg.2020.104077

56. Siddamurthi S, Gutti G, Jana S, Kumar A, Singh SK. Anthraquinone: a promising scaffold for the discovery and development of therapeutic agents in cancer therapy. Future Med Chem. 2020;12(11):1037-69. https://doi.org/10.4155/ fmc-2019-0198

57. Kumar R, Harilal S, Parambi DGT, Narayanan SE, Uddin MS, Marathakam A, et al. Fascinating chemo preventive story of wogonin: a chance to hit on the head in cancer treatment. Curr Pharm Des. 2021;27(4):467-478. https://doi.org/10.21 74/1385272824999200427083040

58. Shalev I, Entringer S, Wadhwa PD, Wolkowitz OM, Puterman E, Lin J, et al. Stress and telomere biology: a lifespan perspective. Psychoneuroendocrinology. 2013;38(9):1835-42. https://doi. org/10.1016/j.psyneuen.2013.03.010

59. Humphreys KL, Esteves K, Zeanah CH, Fox NA, Nelson CA 3rd, Drury SS. Accelerated telomere shortening: Tracking the lasting impact of early institutional care at the cellular level. Psychiatry Res. 2016;246:95-100. https://doi.org/10.1016\%2Fj. psychres.2016.09.023

60. Puterman E, Gemmill A, Karasek D, Weir D, Adler NE, Prather $A A$, et al. Lifespan adversity and later adulthood telomere length in the nationally representative US Health and Retirement Study. Proc Natl Acad Sci U S A. 2016;113(42):E6335-42. https://doi.org/10.1073/pnas.1525602113

61. Coimbra BM, Carvalho CM, Moretti PN, Mello MF, Belangero SI. Stress-related telomere length in children: a systematic review. J Psychiatr Res. 2017;92:47-54. https://doi.org/10.1016/j. jpsychires.2017.03.023

62. Epel ES, Prather AA. Stress, telomeres, and psychopathology: toward a deeper understanding of a triad of early aging. Annu Rev Clin Psychol. 2018;14:371-97. https://doi.org/10.1146/ annurev-clinpsy-032816-045054

63. Ridout KK, Levandowski M, Ridout SJ, Gantz L, Goonan K, Palermo $D$, et al. Early life adversity and telomere length: $a$ meta-analysis. Mol Psychiatry. 2018;23(4):858-1. https://doi. org/10.1038\%2Fmp.2017.26

64. Mayer SE, Prather AA, Puterman E, Lin J, Arenander J, Coccia M, et al. Cumulative lifetime stress exposure and leukocyte telomere length attrition: the unique role of stressor duration and exposure timing. Psychoneuroendocrinology. 2019;104:210-8. https://doi.org/10.1016/j.psyneuen.2019.03.002

65. Mayer SE, Prather AA, Puterman E, Lin J, Arenander J, Coccia $M$, et al. Racial discrimination and telomere shortening among African Americans: the coronary artery risk development in young adults (CARDIA) Study. Health Psychol. 2020;39(3):20919. https://doi/10.1037/hea0000832

66. Parks CG, DeRoo LA, Miller DB, McCanlies EC, Cawthon RM, Sandler DP. Employment and work schedule are related to telomere length in women. Occup Environ Med. 2011;68:582-9. https://doi.org/10.1136\%2Foem.2010.063214

67. Lai TP, Wright WE, Shay JW. Comparison of telomere length measurement methods. Philos Trans R Soc Lond B Biol Sci. 2018;373(1741):20160451. https://doi. org/10.1098\%2Frstb.2016.0451

68. Fasching $\mathrm{CL}$. Telomere length measurement as a clinical biomarker of aging and disease. Crit Rev Clin Lab Sci. 2018;55(7):443-65. https://doi.org/10.1080/10408363.2018.1504274

69. Ennour-Idrissi K, Maunsell E, Diorio C. Telomere length and breast cancer prognosis: a systematic review. Cancer Epidemiol Biomarkers Prev. 2017;26(1):3-10. https://doi. org/10.1158/1055-9965.epi-16-0343

70. Samavat $H$, Xun X, Jin A, Wang R, Koh WP, Yuan JM. Association between prediagnostic leukocyte telomere length and breast cancer risk: the Singapore Chinese health study. Breast Cancer Res. 2019;21(1):50. https://doi.org/10.1186/ s13058-019-1133-0

71. Michelon L. Investigação da associação de variantes polimórficas, sítios de metilação e tamanho de telômeros com resposta a longo prazo de lítio em transtorno bipolar. [tese]. São Paulo: Faculdade de Medicina da Universidade de São Paulo; 2019. https://doi.org/10.11606/T.5.2019.tde-25102019-131555

72. Frenkel M, Mishra BM, Sen S, Yang P, Pawlus A, Vence $L$, et al. Cytotoxic effects of ultra-diluted remedies on breast cancer cells. Int J Oncol. 2010;36(2):395-403. https://doi. org/10.3892/ijo_00000512

73. Bae K, Kim E, Choi JJ, Kim MK, Yoo HS. The effectiveness of anticancer traditional Korean medicine treatment on the survival in patients with lung, breast, gastric, colorectal, hepatic, uterine, or ovarian cancer: a prospective cohort study protocol. Medicine (Baltimore). 2018;97(41):e12444. https:// doi.org/10.1097\%2FMD.0000000000012444

74. Schutte NS, Malouff JM, Keng SL. Meditation and telomere length: a meta-analysis. Psychol Health. 2020;5:1-15. https:// doi.org/10.1080/08870446.2019.1707827

75. Teixeira MZ. Antropologia Médica Vitalista: uma ampliação ao entendimento do processo de adoecimento humano. Rev Med (São Paulo). 2017;96(3):145-58. https://doi.org/10.11606/ issn.1679-9836.v96i3p145-158

76. Teixeira MZ. Isopathic use of auto-sarcode of DNA as antimiasmatic homeopathic medicine and modulator of gene expression? Homeopathy. 2019;108(2):139-47. https://doi. org/10.1055/s-0038-1676810

77. Teixeira MZ. Correlation between vitalism and genetics according to the paradigm of complexity. Homeopathy. 2020;109(1):30-6. https://doi.org/10.1055/s-0039-1692162 